\title{
Van Mobilisering na Transformasie: Die era van Suid-Afrika se militêre hoogbloei met die Vaaldriehoekse samelewing (1974-1994) as konsentrasieveld
}

\section{S.M. (Fanus) Fourie}

\section{Inleiding}

Die toenemende belangrikheid van militêre aktiwitiete het ook 'n invloed op die Vaaldriehoek gehad. Dit was die onafhanklikheidswording van Mosambiek en Angola wat die militêre aspek sterk op die voorgrond laat tree het. Na die SuidAfrikaanse inmenging in die Angolese Burgeroorlog is die Suid-Afrikaanse samelewing toenemend vermilitariseer. ${ }^{1}$ Sedert 1975 is verskillende pogings aangewend om die Vaaldriehoek by die verdedigingspoging betrokke te kry.

2 .

\section{Die Tydperk Voor 1974}

Daar was reeds sedert die vyftigerjare 'n veldtog teen Suid-Afrika geloods. Die veldtog was hoofsaaklik as gevolg van die binnelandse beleid wat sedert 1948 gevolg is. Sedert die sestigerjare was daar biokotte, pogings tot sanksies en binnelandse verset. ${ }^{2}$ Die Sharpeville voorval van Maart 1960 was as gevolg van die protesaksie teen die dra van pasboeke. 'n Noodtoestand is afgekondig en Vaaldriehoekse eenhede is vir 'n kort tyd gemobiliseer. ${ }^{3}$ Die voorval het indirek tot die gewapende stryd aanleiding gegee. Die gewapende stryd, tesame met die terroriste oorlog in die buurstate en gerugte van moontlike konvensionele optrede teen Suid-Afrika en boikotaksies het tot die formulering van die aanslag gedagte

Vgl. Anon, "Sedert Operasie Savannah tien jaar gelede...: SAW wapentuig stukke beter", Paratus, 40(5), Mei 1989, p 9.

H. R. Pike, A history of communism in South Africa (Sygma, Pretoria,1985), p 333. 
gelei. ${ }^{4}$ Daar was egter ook aan die begin van die sewetigerjare vredespogings, soos die détente pogings van mnr. John Vorster en sekere Afrika leiers. ${ }^{5}$

Dit was egter die staatsgreep in Portugal in 1974 en die gevolglike onafhanklikheidswording van Mosambiek en Angola wat die magsbalans in Suider Afrika versteur het. ${ }^{6}$ Daar is gemeen dat inmenging deur moondhede soos Amerika en Rusland in Angola neo-kolonisme was. ${ }^{7}$ Die Suid-Afrikaanse betrokkenheid by die Anglose burgeroorlog in 1975 het die militêre dimensie van die stryd om SuidAfrika op die voorgrond geplaas. Alhoewel daar reeds voor 1974 pogings was om die publiek van die stryd bewus te maak, het die militêre aksie van 1975 in Angola gelei tot die mobilisering van die gemeenskap. ${ }^{8}$

\section{Strategiese Belangrikheid}

Die Vaaldriehoek is deel van die PWV-kompleks, wat ook as die grootste industriële kompleks in Afrika beskryf is. ${ }^{9}$ Die streek se geografiese ligging is feitlik in die middel van Suid-Afrika. ${ }^{10}$ Daar was ook in die Vaaldriehoek nywerhede van nasionale belang, soos Iscor en Sasol. ${ }^{11}$ Daar was ook talle ander nywerhede wat belangrik was soos Dorbyl en Vecor. Daar was ook 'n konsentrasie van kragstasies in die Vaaldriehoek. ${ }^{12}$

Beide die nywerhede en die kragstasies in die streek het hulle ontstaan te danke aan die ryk steenkool neerslae in die omgewing. Steenkool was 'n strategiese komoditiet. Daar is gemeen dat steenkool die ekonomie se wiele aan die gang hou. Die strategiese rol van steenkool is uitgelig na energiekrisis van $1974 .^{13}$ Suid-Afrika

Vgl. B.J. van der Walt, "Totalitêre aanslag teen die RSA", Paratus, 30(7), Jul 1979, p 28.

D. Prinsloo, Stem uit die Wildernis: 'n Biografie oor oud-pres. PW Botha (Mosselbaai, Vaandel, 1997), p 62; R. Lacour-Gayet, A history of South Africa (London, Cassel, 1977), p 342.

D \& J. de Villiers, PW (Kaapstad, Tafelberg, 1984), p 226; Anon, "De huidige militaire situasie", De Zuidafrikaansche koerier, 9(9), Sep 1974, p 2.

Anon, "SA het oplossing vir Afrika se probleme", in Vaalweekblad, 4 Jun 1976. p 8 .

P. L. Moorcroft, Africas Superpower (Johannesburg, Sygma, 1981), p 65.

Anon, Pamflet: Vereeniging, s.d, p 4.

Anon, "Hartland is bewus van sekuriteit", in Vaalweekblad, 27 Aug 1985, p .3.

Vgl. L.H. Gann \& P. Duignan, South Africa: War, revolution Peace? (Stanford, International Studies, 1979), p 25.

Anon, Pamflet: Escom, "Evkom se kragstasies en die nasionale net", Databank nnr. DB/AP/5, Aug 1985, p 1.

C. Dönhoff, Das Südliche Afrika und die Welt-Energiekrise", Afrika Post, 21(3), Feb 1974, p 43. 
het die implikasies van die rewolusie in Iran in 1979 ondere as gevolg van steenkool oorleef. Die gebeurtenis het ook die Sasol projek gestimu leer.

Die waterbronne van die streek was ook van nasionale belang. Die Vaaldam en Randwaterraad se pompstasies en suiwerings aanlegte in die omgewing verskaf water aan streke ver buite die grense van die Vaaldriehoek. ${ }^{15}$ Die padbrûe en die teinbrug oor die Vaalrivier verleen ook die streek 'n strategiese belangrikheid. 'n Groot deel van vrag wat vir state noord van Suid-Afika bestem was het oor die brug by die Vaalrivier gegaan. ${ }^{16}$ Die snelweë wat deur en om die Vaaldriehoek gaan verbind die streek met die res van die land. Lughawens in die streek soos die Vereenigingse lughawe wat as alternatief vir Johannesburg internasionaal kon dien. $^{17}$ Die lugbaken by Meyerton speel ook 'n belangrike rol in die regulering van lugverkeer. $^{18}$

Die aspekte wat hierbo uitgelig is, verleen aan die Vaaldriehoek ook 'n bepaalde militêr strategiese waarde. ${ }^{19}$ Daar is gemeen dat in die geval van 'n volskaalse konvensionele oorlog die Vaaldriehoek ook 'n teiken sou wees. ${ }^{20}$

\section{Mobilisering van die Vaaldriehoekse blankes}

\subsection{Meganismes van mobilisasie}

Daar is veral na 1974 gepoog om die publiek by die militêre stryd te betrek. Dit het plaasgevind op verskillende wyses. Daar was verskillende geleenthede waar daar gepoog is om die gemeenskap te mobiliseer. Ten einde die publiek te mobiliseer is ook klem op paraatheid geplaas.

Vaaldriehoekers is ook gewys op die binnelandse toestand en die toestand in Suider-Afrika. ${ }^{21}$ Vaaldriehoekers is ook teen die Rooi gevaar en die aanslag

Anon, "Iran severs ties, cuts off SA oil", in Citizen, 05.03.1979; Anon, "Geskiedenis "n suksesverhaal", in Sasol bylae in Beeld, 28 Apr 1989, p 2.

R. L. Leigh, Vereeniging (Johannesburg, Courier, 1968), p 154.

Ibid, p 94.

Anon, "Ons is nou sterker sê minister", in Vaalweekblad, 10 Jun 1977; Anon, "Belangrikheid van vliegveld nie altyd besef", in Vaalweekblad, 19 Nov 1982; Onderhoud, Mnr. Kingsley Bell, 24 Feb 2000.

Anon, "Lugruimtes en lugroetes", Paratus, 24(12), Des 1973, p 11; W.C. Gouws, Meyerton na honderd jaar: Feesblad van die stadsraad van Meyerton 1891/92. 1991/92 (Meyerton, Meyerton stadsraad, 1992), p 116.

Anon, "Terro-teiken is veilig, paraat", in Vaalweekblad, 18 Aug 1981, p 2.

B. Pogrund, "Why an invasion of SA would be impossible", in Rand Daily Mail, 29 Oct 1969; R.A Edwards, "Security problems in southern Africa", Paratus, 24(6), Jun 1973, p 7; A. Keppel-Jones, When Smuts goes: A history of South Africa from 1952-2010 (Pietemaritzburg, Shuter \& Shooter, 1949), pp 184-185. 
gewaarsku. $^{22} \quad$ Vaaldriehoekers is ook gemaan om nie onverskillig teenoor betrokkenheid by die weermag te staan nie. ${ }^{23}$ Klem is ook op die feit gelê dat elke weerbare man nodig was om Suid-Afrika te verdedig. ${ }^{24}$ Meneer F.W de Klerk het na die titaniese stryd wat die regering stry om die Weste wakker te skud verwys. ${ }^{25}$ Vaaldriehoekers is ook met die begrip die 'totale aanslag' teen Suid-Afrika bekend gemaak. ${ }^{26}$ Met die ondertekening van die Verdrag van Nkomati in 1984 is daar gewaarsku dat die aanslag nie iets van die verlede is nie. ${ }^{27}$

Sprekers van die polisie en van die weermag is uitgenooi om by jeugverenigings, vroueorganisasies, kerke en skole op te tree. ${ }^{28}$ Tydens feesdae soos republiekdag en geloftedag is die aanslag op die grense ook uitgelig. ${ }^{29}$ Ook geleenthede soos tentoonstellings het groot weermag en polisie uitstallings gehad. Die Vaalskou is verkeie kere deur hoogwaardigheidsbekleërs van die polisie en die weermag geopen. ${ }^{30}$ Dit het ook geblyk dat mense juis as gevolg van sulke uitstallings moeite gedoen het om tentoonstellings by te woon.

Die plaaslike pers in die vorm van die Vaalweekblad, Vereeniging \& Vanderbijlpark News en die Vaal Ster het ook 'n groot rol in die mobilisering van die gemeenskap gespeel. Heelwat artikels het op veiligheid en die belangrikheid van die Vaaldriehoek gefokus. verskyn waarin Die Vaaldriehoekse veiligheidsmagte is ook deur middel van fotos en berigte aan die publiek bekend gestel. Daar was ook strokies prente soos Opdrag Geheim wat oor 'n terroriste aanslag op 'n groot

Anon, "Paniekerigheid is onnodig, sê min. Mulder", in Vaalweekblad, 01 Okt 1976. p 4; Anon, "Dis 'n aapassingsjaar sê sakekamer", in Vaalweekblad, p 20.

Anon, "Mense van SA teen Rooies gewaarsku", in Vaalweekblad, 01 Nov 1976, p 48; Anon, "Kommentaar: Lang arm is 'n vriend, nie vyand", in Vaalweekblad, 28 Sep 1984, p 35; Anon, "Slegs Kruis sal hamer en sekel oorwin", in Vaalweekblad, 02 Mrt 1979, p 29.

Anon, "Vaalweekblad kommentaar: Raak betrokke of...", in Vaalweekblad, 13 Nov 1979 , p 35.

Anon, "Elke weerbare man moet SA help verdedig, sê brigadier", in Vaalweekblad, 03 Des 1976, p 23.

Anon, "Raak betrokke vra minister", in Vaalweekblad, 06 Apr 1979, p 3.

Anon, "Totale aanslag teen Republiek", in Vaalweekblad, 19 Jun 1979, p 6.

Anon, "Aanslag teen SA nie iets van die verlede nie", in Vaal Ster, 12 Okt 1984, p 1.

Anon, "Nellies hoor van motivering vir seuns", in Vaalweekblad, 02 Mrt 1979, p 7;

Anon, "Terroriste kry te veel publisiteit", in Vaalweekblad, 04 Mei 1979, p 14.

Anon, "SA moet alles inspan om stryd te oorleef", in Vaalweekblad, 09 Jun 1976, p 20.

Anon, "VIP's at Vaal Show", in Vaalweekblad, 09 Okt 1992, p 6; G.J. Joubert,

"Kommisaris open Vaalskou", Servamus, Jan 1989, p 16. 
fabriek gehandel het. ${ }^{31}$ Daar was ook advertensies waar verdediging die tema was. Die Toyota 1200 bakkie is geadverteer met die woorde 'Hier kom die pantserbakkie', teen die agtergrond van 'n olifant tenk. ${ }^{32}$ Daar is ook 'n betrekking deur Thorold en van Wyk geadverteer waar militêre opleiding 'n voorvereiste was. $^{33}$

Daar was ook films wat weermag en polisie gebasseer is wat in die streek vertoon is. Die publiek is aangemoedig om die grensfilms te gaan kyk. Gewilde fims

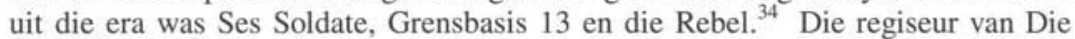
Rebel, Daan Retief, het self die film in die Vaaldriehoek kom bekendstel. ${ }^{35}$ Daar was ook grats filmvertonings wat vertoon is met die doel om die publiek aan terrorisme en misdaad bekend te stel. ${ }^{36}$

Daar het ook dikwels weermag vermaakgroepe in die Vaaldriehoek besoek kom aflê. ${ }^{37}$ Verskeie weermag orkeste en groepe het in die Vaaldriehoek opgetree. Orkeste van bekende regimente het die musiek tydens inspeksie parades van noodhulporganisasie verskaf. ${ }^{38}$ Weermag orkeste het ook tydens die vaalskou opgetree. $^{39}$

\subsection{Die rol van die vrou en jeug in die proses van mobilisasie}

Daar is veral gepoog om die vrou en die jeug te mobiliseer. Die manlike deel van die blanke gemeenskap was reeds in 'n sekere mate gemobiliseer omdat hulle aan vepligte militêre diens bloot gestel is.

\subsubsection{Die rol van die vrou}

C. Bruwer, "strokiesprent: Opdrag Geheim", in Vaalweekblad, 06 Mrt 1978, p 8.

Anon, "Advertensie: Die nuwe Toyota bakkie wat by Phillip Motors te koop was", 03 Feb 1978, p 30.

Anon, "Advertensie: Thorold en van Wyk", in Vaalweekblad, 29 Aug 1980.

Vgl. Anon, "Advertensie: SES SOLDATE - vind byval by oud en jonk", in Vaalweekblad, 25 Apr 1975; Anon, "Pret 'n vermaak: Grens-aksie in nuwe film", in Vaalweekblad, 09 Feb 1979, p 29.

Anon, "Daan Retief nooi Driehoek: Los TV en kyk na 'Die rebel' ", in Vaalweekblad, 14 Mei 1976,p 21.

Anon, "Films oor terrorisme, misdaad", in Vaalweekblad, 14 Mrt 1975.

Anon, "Pret en vermaak: SAW-orkes en grapjas Al Debbo op Sasolburg", in Vaalweekblad, 20 Mei 1980, p 13.

Anon, "Foto: Die Light Horse Regimentsorkes het tydens die inspeksieparade van die Suid-Afrikaanse Rooikruisvereninging...", in Vaalweekblad, 26 Okt 1979, p 39.

Anon, "Jong orkes van weermag speel ook hier", in Vaalweekblad, 21 Sep 1979, p 21 . 
Daar is egter gemeen dat die vrou 'n besondere rol kon speel deurdat sy die vegtende man kon ondersteun en aanmoedig. Verskillende vroue organisasies, soos die damesvereniging van die nasionale party, van die verskillende militêre eenhede en die polisie se damesvereniging in die Vaaldriehoek het dan ook hulle self op hoogte van veiligheidsituasie gehou. Sprekers van die veiligheidsmagte of die gades van ministers is gereeld na hulle byeenkomste uit genooi. ${ }^{40}$ Vroue organsiasies het ook aktief die veiligheidsmagte ondersteun. ${ }^{41}$ Vroue het 'n vername ondersteunende rol in die mobilisasie proses gespeel. ${ }^{42}$ Die eggenote minister van bosbou, mev. Martina Botha het byvoorbeeld aan die Afrikaanse Dameskring op Vanderbijlpark gesê dat vroue die stukrag agter die polisie en die weermag moes wees. $^{43}$

Vroue uit die Vaaldriehoek was ook lede van die weermag. 'n Aantal meisies het oor die jare opleiding by die Burgerlike Beskermingskollege op George ondergaan. ${ }^{44}$ Vroue was ook lede van Vaaldriehoekse eenhede. ${ }^{43}$

\subsubsection{Mobilisering van die jeug}

Daar is ook pogings aangewend om die jeug te mobiliseer. Jeugorganisasies het op die weermag staat gemaak vir velduitrusting tydens kampe. Kinders is ook bekend gestel aan aspekte soos skiet, kamoeflering en die veiligheidsituasie. $^{46}$

Kadette het 'n prominente deel van die opvoeding van Hoërskool seuns uitgemaak. Die doel was dat hulle daardeur vir diensplig voorberei moes word. ${ }^{47}$

Anon, "Mev. Magnus Malan die spreekster", in Vaalweekblad, 29 Jun 1979, p 104.

Anon, "Vroue blad: Wees trots op vegtende man", in Vaalweekblad, 15 Mrt 1983, p 11.

Anon, "Vrou het vername plig in stryd teen terrorisme", in Vaalweekblad, 29 Aug 1975, p 7; Anon, "Gewese Vaal-vrou is patriot sê Paratus", in Vaalweekblad, 26 Mrt 1976, p 10.

Anon, "Vrou moet stukrag agter Polisie en weermag wees", in Vaalweekblad, 25 Nov 1977, p 78.

Anon, "Lorraine will train in civil defence", in Vereeniging \& Vanderbijlpark news, 01 Nov 1974, s.b.; Anon, "Dogter leër toe", in Vereeniging \& Vanderbijlpark News, 21 Nov 1975, s.b.; Anon, "Vrou staan haar plek in SAW vol", in Vaalweekblad, 09 Sep 1980, p 11.

Anon, "When women join the Defence force", in Vereeniging \& Vanderbijlpark News, 04 Feb 1977, s.b.

Onderhoud, Mnr. F.J.P.R. Botha, 26 Jun 2000, Streeksleier Vootrekkers Vereeniging tot 1994.

Anon, "Kadetopleiding as voorloper", in Vaalweekblad, 05 Nov 1976, p 8; Anon, "Kommentaar: Span almal in ", in Vaalweekblad, 26 Aug 1980, p 35; Anon,

"Kadetopleiding belangrik", in Vaalweekblad, 20 Okt 1989, p 24. 
Vaaldriehoekse kadette het gepresteer tydens kadetkompetisies. Daar was ook kadet parades wat deur bevelvoerders van Vaaldriehoekse eenhede geïnspekteer is. Die verkenningsoldaat, Wynand du Toit, het ook in die Vaaldriehoek praatjies gelewer as teen propaganda maatreël. ${ }^{48}$

Vaaldriehoekse blanke jeugdiges het ook tydens veldskole met sekere militêre aspekte soos roetemarse, inspeksies, hindernisbane en ideologiese lesings kennis gemaak. ${ }^{49}$ Vootrekkers het ook militêre aspekte geoefen en basisse besoek. ${ }^{50}$

Kleuterskole is by die mobilsasie proses betrek. Militêre eenhede het dikwels besoeke vir kleuterskole gereël. ${ }^{51}$ Kleuterskole het ook kostuumparades gehou waartydens kleuters met militêre uniforms geparadeer het. ${ }^{52}$

\subsection{Werwing}

Nog 'n meganisme van mobilisering was werwing. Die grote van die Vaaldriehoek het daartoe gelei dat Generaal-majoor Neil Webster het 'n beroep op Engelsspekendes in die streek gedoen om by die staandemag aan te sluit. ${ }^{53}$

\section{Ondersteuning van die Vaaldriehoekse veiligheismagte}

Daar was ook pogings aangewend om die veiligheidsmagte moreel en geldelik te ondersteun. Die Suiderkruisfonds en die Rotariers het byvoorbeeld fondsinsamelingsprojekte geloods om die grens soldate te ondersteun. Vroue het ook 'n groot inset in die Suiderkruisfonds gelewer. ${ }^{54}$ Die Transvaalse Landbou-unie het ook geld ingesamel. Kerke en vroue organisasies het egter ook in tye van onluste

Anon, "Kerknuus: Wynand du Toit praat oor sy Angola ervaring", in Vaalweekblad, 04 Aug 1989, p 56; Vgl. ook C. Vermak, "Freed Wynand is morale booster for troopies", in Citizen, 06 Okt 1988.

Anon, "Veldskool vir dorpskinders was toe sommer reg", in Vaalweekblad, 25 Feb 1977, p 6; Anon, "Veldskool deel van opvoeding", in Vaalweekblad, 06 Aug 1982, p 4.

Anon, "Children need not to be afraid of the military", in Vaal Ster, 23-27 Sep 1991, p 12.

Anon, "Foto: Hierdie twee kordate soldaatjies ...." in Vaalweekblad, 20 Okt 1989, p 18; Anon, "Kleuterskool maak nader kennis met weermag", in Vaalweekblad, 09 Apr 1993, p 7.

D. Jensen, "Kleuters pronk in ander vere", in Vaalweekblad, p 19.

Anon, "Plea from general - Enlish must join: Forces language gap too wide", in Vereeniging \& Vanderbijlpark News, 22 Aug 1975, p 1.

Anon, "Hoë moreel is land se magtigste wapen", in Vaalweekblad, 21 Mrt 1980, p 102. 
etes aan die veiligheidsmagte verskaf. ${ }^{55}$ Daar was ook pogings aanwend om rygeleentehede vir dienspligtiges van die streek te organiseer. Daar is ook reëlings getref om die terug gekeerde soldate weer by die samelewing te laat inskakel. Die sakesektor het ook pogings aangewend om soldate wat diens verrig te gemoet te kom met salarisse en lenings. Daar is ook na die gesinne van grenssoldate omgesien. $^{56}$

\section{Paraatheid en die Vaaldriehoekse gemeenskap}

Ten einde die publiek fisies paraat te mak is daar oefeninge gehou. Paraatheid was dikwels 'n trefwoord. ${ }^{57}$ Benewens oefeninge was die publiek ook ingelig oor wat om te doen indien 'n bomontploffing sou plaasvind. ${ }^{58}$ Daar was ook praatjies oor terrorisme. ${ }^{59}$

Die burgerlike beskerming van die verskillende Vaaldriehoekse dorpe het gereeld oefeninge in samewerking met die Noodhulpliga, St.Johns Ambulans, die weermag en die polisie gehou. Mense is ook aangemoedig om gereed te wees sou noodtoestande ontstaan. ${ }^{60}$ Daar is ook brandbestrydingslesse vir bejaardes aangebied. ${ }^{61}$ Daar was ook noodplanne by skole in plek. ${ }^{62}$ Teen die begin van negentigerjare is daar ook al meer klem op huis en haard verdediging gelê en mense is aangemoedig om by plaaslike kommandos aan te sluit sodate hulle militêr paraat kon wees. Verteenwoordigers van die gemeenskap is ook van tyd tot deur die weermag uitgenooi vir skietoefeninge. ${ }^{63}$

Aan die einde van die tagtigerjare was daar toenemde pogings van die Vaaldriehoekse gemeenskap om homself te beskerm. Die pogings is gekonsolideer in die buurtwag beweging. Daar was selfs buurtwag skoue waartydens hoogeplaasde persone toesprake gelewer het en wapens uitgestal was. ${ }^{64}$ Die sekuriteitswese het

Anon, "Foto: Vroue verbonde aan verskillende kerke .... Kos voor berei vir lede van die Suid-Afrikaanse Polisie wat tydens die onluste diens gedoen het", in Vaalweekblad, 25 Sep 1984, p 5.

Onderhoud, Mnr. C.S Feldman.

Anon, "Paraatheid is hier 'n noodsaaklikheid", in Vaalweekblad, 02 Des 1977.

Anon, "Bomontploffing: wat om te doen", in Vaalweekblad, 10 Feb 1989, p 23.

Anon, "Kenner praat oor terrorisme", in Vaalweekblad, 07 Mar 1979,

Anon, "Kommentaar: Elkeen moet help", in Vaalweekblad, 18 Sep 1979, p 17;

Anon, "Onthou die name en aderesse vir noodtye", in Vaalweekblad, 20 Aug 1976.

Anon, “Leer om brand te bestry", in Vaalweekblad, 09 Feb 1979, p 19.

Anon, "Securtiy is part and parcel of school life", in Vaal Ster, 20 Jun 1986, p 8.

Anon, "Wees paraat nie paniekerig", in Vaalweekblad, 7 Mei 1993, p 4; Anon, "So bly mens aan die lewe in Dodelike Driehoek...; Vroue oefen met Uzzi's, in Vaalweekblad, 1 Apr 1993, p 6.

Anon, "Rothdene buurtwag se fees 'n sukses", in Vaal Ster, 24 Aug 1991. 
ook 'n bloeityd beleef. Die vlaag gewapende rooftogte en die toenemde misdaad in die streek het 'n behoefte by individue en sakeondernemings vir beskerming laat ontstaan. Sulke ondernemings het ook al meer para-militêr voorgekom. ${ }^{65}$

\section{Aktiwiteite van die Vaaldriehoekse veiligheidsmagte}

Die Vaaldriehoek was ook 'n groot bron van mannekrag vir die veiligheidsmagte. Daar was heelwat artikels in die plaaslike pers waarin die veiligheidsmagte bekend gestel is. ${ }^{66}$ Dienspligtiges uit die streek het oor die hele land diens gedoen. In die Vaaldriehoek was daar ook ses kommandos en vier regimente. Die hoofkwartiere van hoër formasies soos Groep 17 en 73 Gemotoriseerde Brigade was ook op 'n stadium op Vereeniging gestasioneer. ${ }^{67}$

Die kommandos was verantwoordelik vir die beveiliging van die streek en ook vir sleutelpunte in die streek. ${ }^{68}$ Op 'n stadium was daar ook twee industriële kommandos naamlik, Iscor en Sasol kommando in die streek. ${ }^{69}$ Twee regimente was teen-insurgensie regimente. Daar was ook twee lugafweer regimente in die Vaaldriehoek. $^{70}$ Beide die kommandos en die regimente het grensdiens verrig. ${ }^{71}$

Vaaldriehoekse eenhede het ook aan groot oefeninge deelgeneem. ${ }^{72}$ Sedert 1984 is daar ook aan binnelandse operasies deelgeneem. ${ }^{73}$ Die regimente van

Anon, "Verrassing kom vir baie", in Vaal Ster, 28 Aug 1989, p 18; Onderhoud, Kol. F. Buter, $18 \mathrm{Apr} 2000$, Voormalige polisie adjunk-distrikskommisaris in Vereeniging.

Anon, "Vier beginsels in weermag", in Vaalweekblad, 24 Okt 1975; Anon, "Militêre opleiding: deskundige vertel", in Vaalweekblad, 10 Okt 1975

Anon, "Gemotoriseerde brigade vanuit Vereeniging bestuur", in Vaalweekblad, 16 Mei 1975.

Anon, "Groep 17 spog met skitter jaar van prestasies", in Vaal Ster, 2 Jun 1992; Anon, Commando's main task is safeguarding the people", in Vereeniging \& Vanderbijlpark News, 11 Jul 1975, s.b.

Anon, "Beskerming van werkplek", in Vaalweekblad, 18 Mei 1990; Anon, "Sasolkommando: Hulle beskerm ons kosbare brandstof", Paratus, 30(8), Aug 1979, p 19.

Anon, "Anti-aircraft regiment receives prestige trophy", in Vaal Ster, 16-20 Mrt 1992; Anon, "Regiment Overvaal 10 jaar oud: Bevorderings aangekondig", in Vaalweekblad, 23 Nov 1979.

Anon, "Foto: Die Regiment Vaalrivier is gemobiliseer met die oog op grensdiens", in Vaalweekblad, 31 Jan 1976; S. Wewege, "Groet eers vyand val toe aan", in Uniform, 03 Mei 1976; Onderhoud, Mnr. C.S. Feldman, 27 Jun 2000, Offisier Regiment Overvaal tot 1985.

Anon, "Ons mense maak oorlog in die Vrystaat", in Vaalweekblad, 08 Aug 1975.

A. de Beer, "Operasie palmiet had die meeste swartes se steun", in Vaalweekblad, 26 Okt 1984; M. Schwenn, "Operasie Waghond wys tande", in Vaalweekblad, 04 
die Vaaldriehoek het ook grensdiens op die Messina grens verrig. Die eenhede het ook diens in swart woonbuurte van ander streke verrig soos in Mamelodi en Soweto. $^{74}$

Ander weermagsdele was ook verteenwoordig in die Vaaldriehoek. Alhoewel die huidige militêre basis 'n Britse lugmagbasis gedurende die Tweede Wêreldoorlog was, het die lugmag nie meer tussen 1974 en 1994 'n permanente teenwoordigheid in die Vaaldriehoek gehandhaaf nie. Die vloot was egter ook in die Vaaldriehoek betrokke. 'n Patrollieboot van die vloot het op die Vaaldam diens gedoen. ${ }^{75}$ Die Suid-Afrikaanse Geneeskundige diens het tot in 1999 ' $n$ siekeboeg by die militêre basis op Vereeniging beman. ${ }^{76}$

Die Suid-Afrikaanse Polisie het ook take van 'n militêre aard in die Vaaldriehoek uitgevoer. ${ }^{77}$ Polisiemanne uit die Vaaldriehoek het grensdiens in Rhodesië en in Suidwes Afrika verrig. ${ }^{78}$ Polisiemanne uit die streek het ook diens in Soweto tydens die onluste van 1976 verrig. Diens in swart woongebiede van die streek was ook deel van die verpligtinge van Vaaldriehoekse polisiemanne. ${ }^{79}$

Sedert 1980 het die komponent van die Onluste eenheid wat op vanderbijlpark gestasioneer was, militêre werk in swart woongebiede gedoen. Die eenheid het onder andere met gepantserde voertuie en in kamoefleer uniforms gewerk. Die lede van die onluste eenheid en die weermag het ook nou saamgewerk. Sedert 1990 het die onluste eenheid egter as Afdeling Binnelandse Stab iliteit(ABS) bekend gestaan. Daar is voortgegaan met militêre tipe werk. ${ }^{80}$

\section{Wapenvervaardiging in die Vaaldriehoek}

Vaaldriehoekse nywerhede was ook op grootskaal by wapenvervaardiging betrokke. Vaaldriehoekse nywerhede het reeds gedurende die Tweede Wêreldoorlog 'n belangrike bydrae tot die vervaardiging van krygstuigstuig gelewer. ${ }^{81}$ Die

Mei 1990, p.1: Anon, "Operasie Skildwag ook in Vaaldriehoek", in Vaal Ster, 1 Feb 1991.

Anon, "Bedrywige 21 jaar", in Vaalweekblad, 2 Nov 1990.

Onderhoud, Mnr. D.J. Manten, Eienaar Manten Marina - verskaf fasiliteite aan SA Vloot op Vaaldam, 4 Apr .2000.

Onderhoud, Mnr. C.S. Smit, 15 Des 1999, Mediese skakeloffisier Groep 171993 1999.

Anon, "Een groot lewensgevaarlike avontuur", in Vaalweekblad, 17 Feb 1981.

Anon, "SAP ook oop grens", in Vaalweekblad, 3 Jun 1988.

Anon, "SAP aanvaar uitdaging", in Vaalweekblad, 20-24 Jan 1992.

Anon, “Afdeling Binnelandse Stabiliteit”, Servamus, Mei 1992, p 19.

Anon, "Drie oorloë raak Vereeniging", in Vaalweekblad, 5 Nov 1992. 
betrokkenheid van Vaaldriehoekse fabrieke sedert 1975 het meegebring dat die streek ook ekonomies gebaat het en deurdat bykomende werksgeleenthede geskep is.

Alhoewel Operasie Savanna die stimulus vir wapenvervaardiging in die Vaaldriehoek was, was daar fabrieke wat reeds voor 1974 daarby betrokke was. Pantserstaal vir die vervaardiging van die Eland pantserkar is by ' $\mathrm{n}$ groot fabriek vervaardig. ${ }^{82}$ By ' $n$ ander fabriek is die staal vir lope en ammunisie vervaardig. ${ }^{83}$ Nog 'n fabriek het die kabels en bedrading vir militêre gebruik gelewer. ${ }^{84}$

Nadat sekere tekortkominge in Suid-Afrikaanse krygstuig na die Angola veldtog geïdentifiseer is, het Vaaldriehoekse fabrieke 'n groot inset in die vervaardiging van nuwe krygstuig gelewer. ${ }^{85}$ Die G5 en G6 kanon is met die insette van Vaaldriehoekse fabrieke vervaardig. Vaaldriehoekse ingenieuers het 'n belangrike rol in die ontwikkeling van ' $n$ nuwe tipe pantser-en loopstaal gespeel. ${ }^{86}$ 'n Groot Vaaldriehoekse staalfabriek was byvoorbeeld die enigste verskaffer van pantserstaal. ${ }^{87}$

Daar was ook fabrieke wat komponente van pantservoertuie en kanonne gelewer het. ${ }^{88}$ 'n Fabriek het ook die klaarvervaardigde infanterie granaat lanseerder, die stopper geweer en 'n $9 \mathrm{~mm}$ sub-masjiengeweer gelewer. ${ }^{89}$ 'n Vaaldriehoekse fabriek het ook komponente vir die Rooikat aanvalshelikopter gelewer. Talle ander kleiner fabrieke het onderdele vir verkillende wapentuig gelewer. ${ }^{90}$

\section{Die rewolusionêre stryd}

Polities was die Vaaldriehoek sedert 1984 een van die brandpunte. Die 1984 onluste siklus het op 4 September 1984 in die Vaaldriehoek begin. Alhoewel daar werklike griewe was, soos die huur verhoging en die toestand in swart onderwys, word daar ook gemeen dat rewolusionêre deel gehad het in die

Onderhoud, Mnr. Gerrie Hoffman, 28 Mrt 2000, Hoofbestuurder Iscor tot 1995.

Onderhoud, Dr. F.W. Guldenpfennig, 14 Feb 2000, Bestuurder staalafdeling Usco 1970-1990.

R.L.Leigh, Vereeniging, p 86.

Anon, "Vaaldriehoek word nywerheidshartland en maak SA meer selfstandig", in Vaalweekblad, 6 Jul 1984, p 7.

Anon, "SA self-sufficient in barrel steel", Salvo, 3-88, nr 17, p .55.

Onderhoud, Mnr. G. Hoffman, 28 Mrt 2000.

Onderhoud, Mnr. P.A.H. Labuschagne, 17 Mei 2000, Hoof ingenieur spesiale kontrakte Broderick.

Onderhoud, Mnr. L.M. le Roux, 31 Jan 2000, Produksie beplanning Mitco 19811994.

Onderhoud, Mnr. Jan Koen, 26 Jun 2000, Kontrakte ingenieur Elca 1986-1994. 
mobilisering van die massa..$^{91}$ Die onluste het van die Vaaldriehoek landwyd uitgekring. ${ }^{92}$ Daar was van tyd tot ernstige voorvalle van onrus in Vaaldriehoek na 1984. Die minister van binnelandse sake en van nasionale opvoeding, mr. F.W. de Klerk, het gemeen dat die onluste 'n totale aanslag teen ordelike ontwikkeling in Suid-Afrika was. Hy het ook gemeen dat die inwoners van Vereeniging moes besef dat daar 'n stryd aan die gang was waarvan niemand sou kon ontsnap nie. ${ }^{93}$ Die rewolusionêre stryd het ook 'n groot deel van die staat se magte in die binneland gebind. ${ }^{94}$ Die onluste situasie het gelei tot die afkondiging van die noodtoestand op 20 Julie $1985 .{ }^{95}$ Daardeur is ook ingrypende magte aan die weermag verleen. ${ }^{96}$

Die onrus situasie het spoedig deel geword van die rewolusionêre stryd. Organisasies soos die UDF en Cosatu het 'n belangrike rol in die mobilisering van die massa gespeel. ${ }^{97}$

Die militêre vleuels van swart organisasies was ook in die Vaaldriehoek bedrywig. Daar was heelwat rekrute vir die ANC se Umkhonto we Sizwe. Hulle het die land verlaat en opleiding op verskillende plekke in die buiteland ondergaan. Daarna het hulle weer terug in die land geïnfiltreer. Heelwat van die mense is weer in die Vaaldriehoek geaktiveer. Hulle was veral betrokke by die konsep van 'peoples war' waar hulle meegehelp het om die massa te mobiliseer. ${ }^{98}$ Daar was ook in swart woongebiede aktiewe verset. Vir korttye was daar bevryde areas. Dienste is vernietig en loofgrawe is oor die toegangspaaie gegrawe. Daar was egter ook gevalle waar MK-lede by sabotasie of poging tot sabotasie in die streek betrokke was. Daar was byvoorbeeld die aanslag op Sasol 1 in Junie 1980. Daar was ook die

M. Hough, Revolt in the townships, in A. Venter(ed.), Challenge: Southern Africa within the Africcan revolutionary context: An overview (Gibraltar, Ashanti, 1989), p 389; S.F. Haasbroek, Massageweld in 'n konfliksituasie: 'n Sosiologiese gevallestudie in Sebokeng aan die hand van Neil Smelser se kollektiewe gedragsteorie (PU vir CHO, ongepub. Verhandeling), p xiii.

C.C. Saunders (ed.), An illustrated dictionary of South African history, p 235.

Anon, "Minister maan oor gevoel van moedeloosheid", in Vaalweekblad, 25 Sep 1984, p 5 .

F. Van Zyl Slabbert, The system and the struggle: Reform, revolt \& reaction in South Africa (Jonathan Ball, Johannesburg, 1989), p 129.

Anon, "Seer van geweld", in Vaalweekblad, 6 Sep 1985.

Staatskoerant, Proklamasie: Verklaring van 'n noodtoestand, nr 9876, 21 Jul 1985.

Anon, "How the ANC/UDF manipulate militant labour", in Aida Parker newsletter, nr 85, 1 Jul 1985, p 17.

Vgl. J. Rantete, The African National Congress and the negotiated settlement in South Africa (Van Schaik, Pretoria, 1998), p 124.

P.H. van der Weel, "Zuid-Afrika heeft nog weinig tyd", in De Telegraaf, 4 Jun 1980. 
geveg op die Goue Hoofweg met die polisie. ${ }^{100}$ Daar is ook 'n aantal wapenopslagplekke ontdek. ${ }^{101}$

Alhoewel Apla ook in die Vaaldriehoek bedrwyig was, was hulle aktiwiteite aanvanklik nie naastenby so prominent as die van MK nie. ${ }^{102}$ Daar was ook nie geslaagde Apla pogings voor 1990 om die Vaaldriehoek met opgeleide lede te infiltreer nie. Eers na 1993 na die aankondiging dat Apla sy aanslag gaan verskerp was daar voorvalle waarin Apla mense in die Vaaldriehoek aangeval het. Voorbeelde daarvan is die Eikenhof voorval in $1993 .{ }^{103}$ Daar was ook die hinderlaag by Orange Farm in Maart 1994 waarin vier polisielede doodgeskiet is. ${ }^{104}$

'n Ander sy van die rewolusionêre stryd in die Vaaldriehoek was die voorkoms van Selfverdedigingseenhede(SVE's). Die eenhede het hoofsaaklik uit jeugdiges bestaan wat hulle onderskeie gebiede met vuurwapens gepatroleer het. ${ }^{105}$ Die SVE's is deur of MK of Apla gerugsteun. ${ }^{106}$

\section{Die impak van mobilisasie}

Die mobilisasie van die gemeenskap het destyds 'n sekere impak op die totale gemeenskap gehad.

\subsection{Polarisasie}

Daar kan gesê word dat groot dele van die blanke en van die swart bevolking gepolraiseer is. Beide kante was oortuig dat hulle vir die regte saak geveg het. Veral swart jeugdiges wat as vegters terug gekeer het was oortuig dat enigste oplossing 'n geweldadige oplossing was. Aan die ander kant het baie blankes geglo dat swart vegters in diens van kommunisme gestaan het en dat kommunisme beveg moes word. Later het etniese geweld ernstige afmetings in die Vaaldriehoek afgeneem. ${ }^{107}$ Die Boipatong voorval het skokgolwe oor die wêreld gestuur. ${ }^{108}$

Onderhoud, Mnr. S.E. Terreblanche, 1 Mei 2000, Oud SAP lid betrokke in eerste terroriste geveg in Vaaldriehoek 1985.

Onderhoud, Kapt.F.P. Van der Walt, 27 Jun 2000, Was voor 1994 seksiebevelvoerder in veiligheidspolisie Vereeniging.

Onderhoud, R.G. Scholtz, 3 Jul 2000, Lid van veiligheidspolisie Vereeniging.

F.E. Gunning, "Dit is MK's wat vas is na Eikemhofmoord", in Rapport, 4 Apr 1993.

Onderhoud, Mnr. en mev. Gouws, 27 Jul 2000, Ouers van konst. P. Gouws.

M. Marks \& P. McKenzie, Militarized youth: Political pawns or social agents?, in J. Cock \& P. McKenzie(eds.), From defence to development: Redirecting militay recources in South Africa (David Phillip, Claremont, 1998), p 224.

Dagboek Vereeniging Kommando, Bevelvoerders konferensie Groep 17, 25 Feb 1991.

Anon, "Residents flee township", in Star, 16 Mrt 1990; P.Sakoane, "Dragged into a war they want no part of", in Vaal Ster, 13-17 Aug 1990. 


\subsection{Die militarisering van die Vaaldriehoekse gemeenskap}

Die blanke gemeenskap is deur amptelike mobilisasie vermilitariseer. Die swart gemeenskap het oorlogstoestande ervaar en beleef. ${ }^{109}$

\subsection{Ongevalle}

Dit is nie bekend hoeveel kaders wat van die Vaaldriehoek afkomstig is iewers in gevegte met veiligheidsmagte gesneuwel het nie. Daar het wel iemand van MK in die vroeë negentiger jare by swart ouers verbygegaan en verslag gedoen oor die omstandighede waaronder hulle seuns dood is. ${ }^{110}$ Aan die ander kant het heelwat Vaaldriehoekse soldate tussen 1974 en 1994 gesneuwel. Na die ontrekking aan Suidwes het die militêre ongevalle ook afgeneem. Afgesien van die gesneuweldes is daar ook 'n aantal Vaaldriehoekers wat ernstig gewond was. ${ }^{111}$

\subsection{Sosiale probleme}

Die besondere situasie waaraan soldate blootgestel is, het daartoe aanleiding gegee dat ook Vaaldriehoekse soldate met die gereg gebots het. Soldate is veroordeel weens die besit van onwettige ammunisie. ${ }^{12}$ Enkele voorvalle van geweldsmisdade wat deur soldate begaan gepleeg is het ook voorgekom. ${ }^{113}$ Daar was ook enkele voorvalle van dwelm misbruik onder Vaaldriehoekse soldate. ${ }^{114}$ Soldate moes ook oor drankmisbruik aangespreek word. ${ }^{115}$ Daar was ook gevalle waar egskeidings as gevolg van militêre diens plaasgevind het. ${ }^{116}$

\subsection{Angsneurose}

P. Mabuye, "Boipatongs agony", in Vaal Ster, 22-26 Jun 1992.

Anon, "Talking points: Talk peace?", in Vaal Ster, 26-30 Apr 1993, p 4; Anon, "Kinderbendes regeer", in Vaalweekblad, 29 Mei 1992; Anon, "Terror and the new South Africa", in Patriot, 31 Jul 1992.

Onderhoud, R.G. Scholtz, 3 Jul 2000.

Anon, "Military honoour for const. Buys", in Vereeniging \& Vanderbijlpark News, 11 Okt 1974; Anon, "Luit. Mike Dreyer op grens dood", in Vaalweekblad, 16 Jan 1987.

Anon, "Gevonnis oor mortier", in Vaalweekblad, 2 Jul 1982.

Anon, "Bajonetmoord: pa tronk toe", in Vaalweekblad, 13 Jun 1980; Anon, "Twee dienspligtiges kry lyfstraf", in Vaalweekblad, 20 Jul 1982; Vgl.ook Anon, "Brief: Depressie na weermag", Huisgenoot, 56(4049), 9 Jul 1998, p 4.

Onderhoud, Mnr. B. Schempers, 29 Mrt 2000, Bevelvoerder Vanderbijlpark Kommando 1976-1983.

Onderhoud, Mnr. M.L. van Stratten, 5 Feb 2000, Oud sersant-majoor Vereeniging Kommando.

Onderhoud, mnr. B. Schempers; Onderhoud, Mnr. M.L.van Stratten, 
Die feit dat daar sabotasie van die Sasol 1 aanleg was en berigte in die media van bomontploffings het mense in 'n sekere mate neuroties gemaak. Dikwels wanneer daar rookwolke in die lug was, het mense navraag gedoen of daar nie dalk 'n bom ontplof het nie. ${ }^{117}$ As gevolg van binnelandse onrus het wapen verkope ook in die Vaaldriehoek skerp toegeneem. ${ }^{118}$ Die geweldsituasie in die Vaaldriehoek het heelwat mense laat besluit om uit die streek te verhuis. ${ }^{119}$

\subsection{Traumatiese ervarings}

Van die soldate en polisiemanne wat in grusame situasies was het jare na die tyd nog probleme om sulke situasies te verwerk. ${ }^{120}$

Ook ouers wat seuns verloor het, het jare daarna nog probleme op dit te verwerk. Daar bestaan gevalle waar ouers en selfs ander kinders in die huisgesin sielkundige hulp moes kry. ${ }^{121}$

Daar bestaan ook enkele gevalle in die Vaaldriehoek waar mense as kinders aan oorlogstoestande blootgestel is. Mejufrou E. Patterton het byvoorbeeld as kind die aanval op Katima Mulilo in 1978 meegemaak. Sulke ervarings bly ook sluimerend vir jare daarna. ${ }^{122}$

Anon, "Digte rookwolke laat talle mense wonder", in Vaalweekblad, 11 Jul 1980; Anon, "Angs ook hier na Pretoria-bom", in Vaalweekblad, 24 Mei 1983.

Anon, "Groot aanvraag na wapens en ammunisie", in Vaalweekblad, 11 Sep 1984.

Anon, "White flee violent Vaal Triangle", in Vaal Ster, 21-25 Feb 1994.

Dagboek, J. Bergh; Onderhoud, J. Bergh, 21 Des 1999, Dienspligtige op grensdiens 1987-1988; Onderhoud, D. Ferreirra, 17 Des 1999, Dienspligtige op grensdiens 1987-1988.

Onderhoud, Mnr. en mev. Sadler, 9 Mei 2000, Ouers van Sandy Sadler; Onderhoud, Mnr. en mev. Taylor, 3 Mei 2000, Ouers van Pieter Taylor. 


\subsection{Die impak op die mens se spel}

Die mens se spel is ook geraak. Daar is modelle van Suid-Afrikaanse krygstuig as projekte by skole gemaak. ${ }^{123}$ Kinders het ook met modelle van SuidAfrikaanse pantservoertuie gespeel. ${ }^{124}$

\section{Transformasie en demobilisasie}

Demobilisasie het plaasgevind as gevolg van die beïndiging van die Koue Oorlog, die ontrekking uit Suidwes-Afrika en die koers van die De Klerk bewind. ${ }^{125}$

Daar kon nie onmiddelik met algehele demobilisering in die Vaaldriehoek begin word nie. Die turbulente politieke situasie van die vroeë negentigerjare het 'n parate weermag en polisie nodig gemaak. Etniese geweld en misdaad was twee vername probleme waarmee die Vaaldriehoekse veiligheidsmagte te kampe gehad het. Daar was egter in die begin van die negentigerjare meer soldate in Suid-Afrika ontplooi as gedurende die grensoorlog. ${ }^{126}$ Die rol van die weermag ook verander. Die weermag is nie meer in die rol aangewend om die land teen buitelandse aggresors te beskerm nie, maar het polisiëringstake begin uitvoer. Die weermag het medeverantwoordelik geword vir die handhawing van handhawing van openbare orde. ${ }^{127}$

Die proses van demobilisasie het ook onsekerheid meegebring. Terwyl die blanke gemeenskap ernstig oor oorlewing gedink het, is daar orals van vrede melding gemaak. Die moreel van die weermag was laag. ${ }^{128}$ Soldate wou nie in swart woongebiede diens doen nie. Aanmeldingsyfers vir kampe was laag. Daar was gevalle waar die End Conscription Campaign soldate aangemoedig het om nie vir militêre diens aan te meld nie. ${ }^{129}$

Terwyl die staat stelselmatig met demobilisasie voortgegaan het, het die regses begin mobiliseer. Regse leërs begin onstaan het. Die AWB was op die

Anon, "Foto: Coert Reyneke kan so ampertjies die modelvoertuig bestuur", in Vaalweekblad, 19 Nov 1985.

Anon, "Speelding help bejaardes", in Vaalweekblad, 12 Apr 1985.

Vgl. Anon, "Uit die begrotingsrede van die minister van verdeging, generaal Magnnus Malan: Dollars and Doves - hoe gaan dit ons raak". Salvo, 2/89, p 9; H. Hough, "Aspects of South African strategic doctrine and the SADF role perception", Paratus, 11(41), Nov 1990, p 55.

Anon, "Comment: The SADF", in Citizen, 17 Jan 1993, p 6.

G. Thiart, "Gebiedsbeskerming brei uit", Paratus, 4(43), Apr 1992, p 10.

Anon, "The agony of our dying Army", in Patriot, 31 Jan 1992; Dagboek Vereeniging Kommando, Bevelvoerderskonferensie Groep 17, 25 Nov 1991.

Anon, "Should call-ups still be compulsory", in Vaal Ster, 7-11 Sep 1992; Anon, "Vanderbijl man arrested for refusing to do military service", in Vaal Ster, 26-30 Sep 1992. 
voorgrond. ${ }^{130}$ Daar is ook 'n tak van die Volksleër op Vereeniging gestig. Die Konserwatiewe party het ook mobiliseer. ${ }^{131}$ Oud-generaals was by die pogings betrokke en was ook by die Vaaldriehoek betrokke. ${ }^{132}$

\subsection{Ekonomiese impak van demobilisasie}

Demobilisasie het ook 'n ekonomiese impak op die Vaaldriehoek gehad. Omdat 'n groot hoeveelheid krygstuig nie meer nodig was nie, is daar ook nie meer verdedigingskontrakte toegeken nie. ${ }^{133}$ Die feit was deels daarvoor verantwoordelik dat werkers afgedank is en dat sekere afdelings van fabrieke moes sluit. Die onvermydelike gevolg van die situasie was werkloosheid. ${ }^{134}$

\subsection{Die ontbinding van Vaaldriehoekse militêre eenhede}

Die proses van demobilisasie is stapsgewys onderneem. Op nasionale vlak is diensplig verkort tot een jaar. ${ }^{135}$

Die finale stap van demobilisasie was die ontbinding van militêre eenhede. In die Vaaldriehoek het drie regimente ontbind. ${ }^{136}$ Die hoofwartier van Groep 17 het ook na Lenz verskuif. Uiteindelik het Groep 17 ook in 1999 ontbind. ${ }^{137}$

\section{Afsluiting}

In die voorafgaande bespreking is daar gesien hoedat die samelewing van die Vaaldriehoek in 'n era van militêre hoogbloei, gemobiliseer is. Daar is ook gesien hoedat die samelewing vir 'n sekere tyd meegevoer deur die era. Nadat die dryfkrag agter die die era, militêre diens op die Suidwes grens, egter verdwyn het, is

Anon, "AWB wil mobiliseer", in Vaalweekblad, 4 Des 1992; Anon, "AWB paves the way to revolution", in Vaal Ster, 22-26 Nov 1993.

Anon, "Mobilisasie op hande - A.P. Treurnicht", in Patriot, 21 Aug 1992.

Anon, "Volksfront dreig met aggresiewe optrede: Net 300 by blanke optog", in Vaal Ster, 24-28 Mei 1993.

D. Henning, "The transformation of armscor - a complex and interesting process", Salvo, 4(96),

P. Batchelor, South Africa's arms industry: Prospects for conversion, in J. Cock \&

P. McKenzie, From development to defence: redirecting military recources in South Africa, p 107.

Onderhoud, Dr. F.W. Guldenpfennig, 14 Feb 2000. Onderhoud, Mnr. P.A.H.

Labuschagne,

16 Jun 2000.

Anon, Pamflet: Persverklaring deur generaal Jannie Geldenhuys op 8 Des 1989.

R. Fitchat, "Regiment Overvaal sluit finaal sy deure", in Vaal Ster, 5 Sep 1997; Onderhoud, A. Joubert,

N. Chandler, "Defence force cuts infantry divisions to the bone", in Star, 26 Jul 1999, p 3. 
mobilisasie deur transformasie vervang. Die era van transformasie het onsekerheid, etniese geweld en regse ekstremisme laat hoogty vier. Transformasie het egter ook tot militêre demobilisasie gelei.

In die tyd van transformasie is die negatiewe impak van die era van mobilisasie ervaar. Fabrieke het nie meer verdedigingskontrakte gekry nie. Afskaling en afdankings was die gevolg. Heelwat ouers wat seuns verloor het, het met die traumatiese vraagstuk van 'dit was alles verniet' geworstel.

Die verdwing van die militêre magsbasis van die blanke bevolking het tot 'n magverliessindroom onder die groep gelei. Aan die ander kant is die swart bevolking met nuwe vraagstukke gekonfronteer waarvoor die struggle nie voorsiening gemaak het nie. 